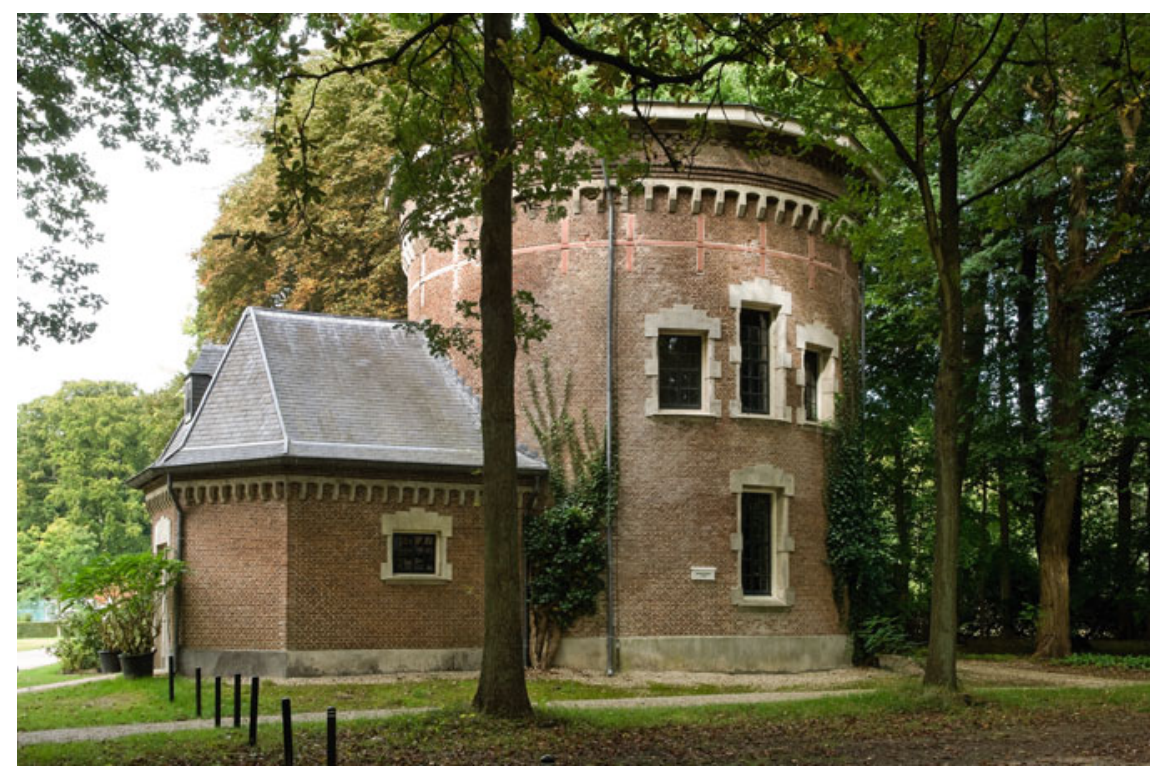

The oldest watertoren of the Netherlands (constructed 1678-1683), served the fountains of the gardens of Paleis Soestdijk, a former palace and hunting lodge of the Dutch Royal Family. The water reservoir was supplied by means of a windmill and a horse drawn mill. Source Beeldbank Rijksdienst voor het Cultureel Erfgoed; released under CC BY-SA 4.0 Photographer Jan van Galen 


\title{
Chapter 5 \\ Thirsty Cities: Learning from Dutch Water Supply Heritage
}

\author{
Suzanne Loen
}

\begin{abstract}
Cities worldwide currently face freshwater shortages. Forecasts predict that demand will outstrip naturally renewable and available water supplies by $40 \%$ by 2030 . This poses a serious threat to livability in cities and urban areas that are already struggling with water-related issues like floods and land subsidence. Water insecurity, in particular, now intensified by climate change, calls for integrated and creative solutions. The Dutch heritage in freshwater management, sometimes overlooked and undervalued due to its utilitarian and often modest orientation, is able to provide knowledge and inspiration toward developing water-secure, water-sensitive cities. Three lessons can be learned from Dutch water supply heritage. First, the quest for clean drinking water has sometimes driven the development of valuable urban greenscapes, waterscapes, and nature and landscape conservation areas. Second, those who initiated and managed water-related innovations were often private and commercial parties which collaborated with public entities. Third, although Dutch water supply heritage has become invisible or is not recognized, it embodies valuable systems and practices, particularly with regard to the multisource water supply, private and collective rainwater harvesting, that today could benefit both water supply and wastewater systems. Reducing the need for clean drinking water, generating less storm water runoff, needs to be done while engaging the public in building water-sensitive, safe cities.
\end{abstract}

Keywords Dutch water supply heritage - Urban drinking water management • Rainwater harvesting $\cdot$ Water-sensitive cities $\cdot$ Water cistern

\footnotetext{
S. Loen $(\bowtie)$

Department of Urbanism, Section Landscape Architecture \& LILA Living Landscapes, Delft University of Technology, Delft, The Netherlands

e-mail: suzanneloen@lilalandscapes.nl 


\section{Introduction}

The Netherlands, with its polders and flood defense systems, is well known as a model nation in sea and polder-boezem (that is, outlet-pool) water management and water heritage. Slightly less famously, it is also an exemple in freshwater supply management. In 1853, the country's first drinking water company delivered piped water in Amsterdam (Leeflang 1974). By 1968, more than $99 \%$ of the Dutch population had access to piped drinking water, and today all households are connected to piped water. One consequence of this transformation is that the country decreased its use of surface water for drinking and, today, $60 \%$ of its freshwater supply comes from groundwater (De Moel et al. 2006). Climate change is expected to intensify the negative effects of groundwater exploitation in both cities and the agricultural hinterland worldwide: depleting water tables, damaging the quality of surface water, and increasing salination.

Dutch systems for accessing drinking water developed from decentralized offthe-grid systems, which included rainwater harvesting, into large-scale centralized urban utility networks with a civil engineering orientation. In the densely populated urban and industrial, western part of the country, an area of low-lying deltas, polders, and coastal regions-more particularly, the cities of Rotterdam and Amsterdamgroundwater sources were often scarce or of poor quality due to brackish conditions, salination, as well as domestic and industrial pollution. Locals met these problems with resourceful public and private innovations and initiatives. In this chapter, such historic local developments, taking place between the Middle Ages and the introduction of centralized piped water utilities networks during the Industrial Revolution, are first presented then placed into national and international perspective. Exploration of historic tangible infrastructure in spatial, architectural, and landscape architectural follows. These interventions were based on drinking water type-whether it was groundwater, surface water, or rainwater. The intangible dimensions of this heritage, that is how the systems were organized, are then addressed. Here, the focus is on the three possible organizational arms: public, communal, and private involved in water management. As governing bodies and private parties require the participation of citizens in developing resilient and water-secure cities, this focus provides insight into how such collaborations were coordinated in the relatively highly urbanized and industrialized areas of the Netherlands. The objective is to investigate and identify lessons to be learned from intangible and tangible Dutch water heritage that can be applied to building water-secure and water-sensitive cities in the future in areas that face overexploitation and pollution of water resources. 


\section{Water Heritage from the Middle Ages to the Nineteenth Century}

Dutch cities were relatively late in implementing centralized piped drinking water facilities compared to other European cities (Leeflang 1974). The cities of London and Paris, for example, introduced piped riverine surface water supply systems during the sixteenth and early seventeenth centuries (Leeflang 1974; Wijmer 1992; Wijntjes 1982). Citizens of Dutch cities generally relied on three types of water for consumption: groundwater, surface water, and harvested rainwater. Residents of cities and villages obtained their drinking water from the surface water in shallow wells, rivers, canals, and brooks (Wijmer 1992). (Figure 1) The urbanized western part of the country, consisting of South Holland, North Holland, Utrecht, and North Brabant, relied mainly on surface water (Vogelzang 1956). Most shallow wells were fed, vertically, with infiltration-storm water runoff, or, horizontally, with surface water from nearby rivers and streams (Rapport aan den Koning van de commissie tot onderzoek van drinkwater 1868). Shortage of water in general was not a problem as the Netherlands had an abundance of rivers, lakes, and canals.

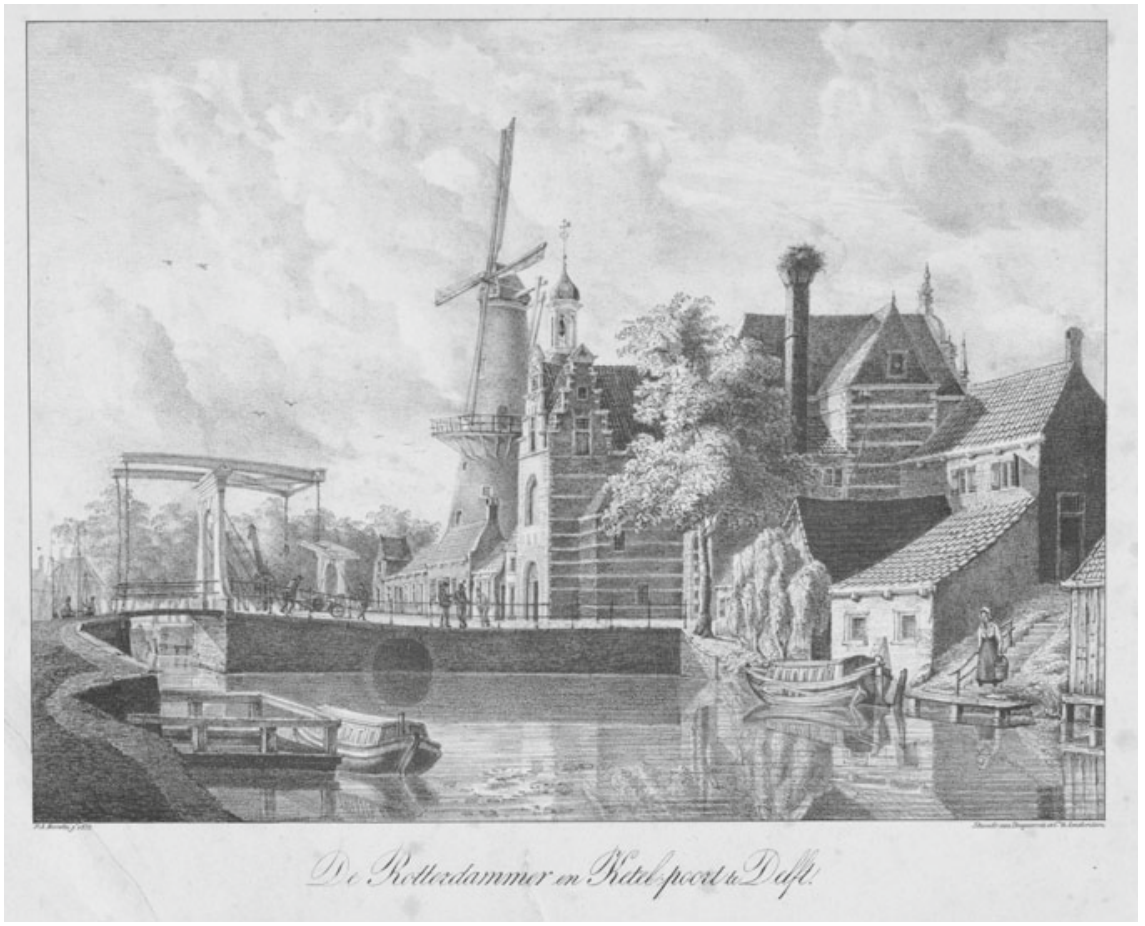

Fig. 1 Detail of a nineteenth-century drawing of a woman fetching water from the canal in the town of Delft by Petrus Augustus Beretta. Source Rijksmuseum; released under a Creative Commons Attribution-NonCommercial-NoDerivatives 4.0 International License 
In the fifteenth century, many Dutch cities began to grow in economic activity. Highly polluting industries within them, such as textile industries, tanneries, and beer breweries, required large quantities of clean water as they flourished and expanded (Wijmer 1992). Along with growth of the urban population, this change affected the self-cleaning capacity of the surface water system (Groen 1978). Securing urban freshwater supply for domestic and economic purposes in cities became very challenging. The quality of urban surface water deteriorated substantially, forcing cities and their inhabitants to build more rainwater reservoirs and drill groundwater wells. In the western part of the country, the drilling of wells often proved unsuccessful (Groen 1978).

In 1868, a commission advised the king of the need for a centralized piped water system (Rapport aan den Koning 1868). In the process, it described the conditions of the water supply system that had characterized Dutch life since the sixteenth century. The commission's research showed that the percentage of deaths due to the waterborne disease cholera was significantly higher in areas where surface water was the dominant source of drinking water than in areas where groundwater was the predominant source. Areas where rainwater predominated as source were the least affected by cholera. The report divided surface water into three subtypes: riverine water from the main rivers; water from the polder system (a closed and controlled water system in contrast to the open riverine system); and water from open surface bodies like shallow wells (putten), ponds, lakes, ditches, canals, smaller rivers, streams, and water from filtration of storm water, zakwater. The water quality in this last category varied substantially. Cities with an open canal system subject to the tides of its main rivers were better off than villages and cities and parts of cities with a closed urban canal system that was not flushed regularly. Villages and cities in polders, in turn, were worse off than these (Rapport aan den Koning 1868).

Water provision in Rotterdam exemplifies the difficulties. The city was serviced by three different water systems: a) the polderwater system, b) the innercity grachtensystem, and c) the riverine system of the River Maas. (Figure 2) The inner city of Rotterdam was divided from the waterfront extension by a dike and surrounded by two large grachten (known also as stadsvesten; these canals were closed off from the river by a sluice). Originally, a defense system-but mostly used as docks and harbors-, the canals did not profit from the influx of freshwater during high tide (Van den Noort and Blauw 2000). Water quality deteriorated substantially over time due to lack of sufficient water flow and domestic and industrial pollution. In the ditches, streams, and canals in the polder surrounding the city, the surface water was affected by stagnation and agricultural pollution. The water quality in the polder was therefore not much better than in the inner city. It was worse than in the waterstad that benefited from the relative clean water from the river Maas. 


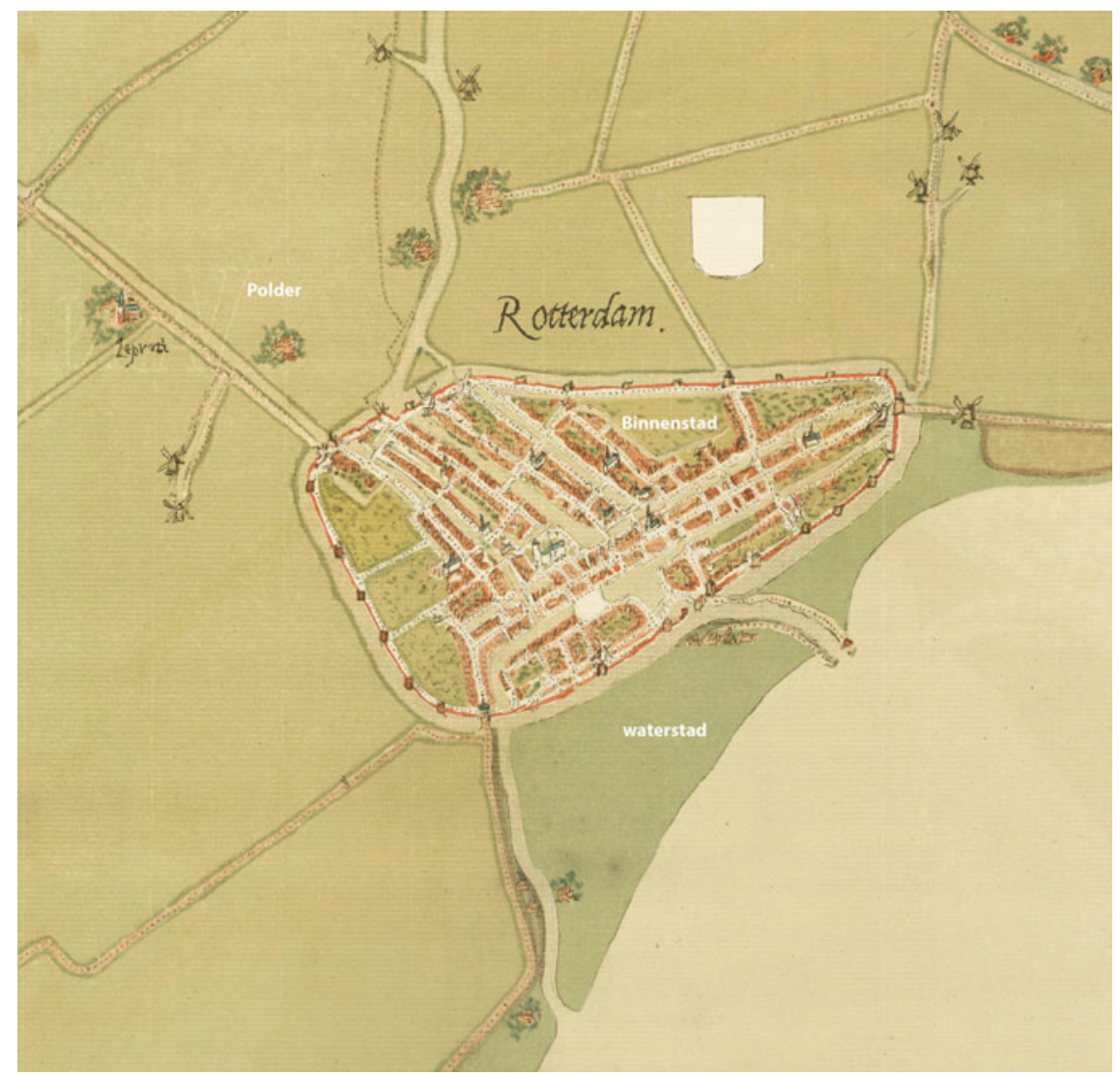

Fig. 2 Map of the inner city of Rotterdam in 1550 by Jacob van Deventer. Source Nationaal Archief; released under a Creative Commons Attribution-NonCommercial-NoDerivatives 4.0 International License

The seventeenth-century extension of the city in the Waterstad, with open harbors, canals, and docks, was subject to river tides. Water was consequently of relatively good quality. There, water was taken directly from surface water bodies and indirectly from water reservoirs, or vloeiputten, a system of arched openings in quay walls and cisterns (Vogelzang 1956): When water rose, surface water entered these openings and flowed through pipes to cisterns located in building or to pumps that then made it available to the public (Vogelzang 1956). City architect W.N. Rose promoted this system in 1840, as he thought the quality of the Meuse water was quite good (Dijkstra 1974). He pointed to one such vloeiput which was already providing water to the public at the Stadstimmerhuis, a public works building located on the outer quay of the waterfront (Dijkstra 1974). 
With the nineteenth-century expansion of the city, the stadsvesten became part of the new polder city, closed off from the open riverine water system. The surface water in this new polder city deteriorated substantially (Van den Noort and Blauw 2000). Dutch polders' inferior water quality can be explained by the traditional attitude of the Dutch water boards to polder water management. The main concern of the water boards was to keep the low-lying peat polders dry, so they set up the water management system to mill as much water out of the polders as possible, rather than letting water in. Maintaining water quality was of secondary importance. The city of Rotterdam could therefore get rid of its dirty water during low tide; however, the water board did not let in freshwater from the Meuse to flush the canals during high tide. In 1840, to tackle this urgent lack of clean drinking water, W.N. Rose proposed building eight more vloeiputten to collect water from the river Meuse at high tide and to carry the water in metal pipes to the dwellings and buildings of the inner city. (Figure 3) A year later he expanded the plan to nineteen. This Waterproject would also provide new and improved sluices, public green water ways [parksingels], and public water wells to both the inner city and the polder city. In addition, it proposed filling up the stadsvesten to turn them into roads. (Dijkstra 1974) (Figure 4).

In spite of the poor quality of surface water, many citizens continued to throw a bucket into the canals, ponds, or ditches to retrieve water for their needs. The city did provide water from city wells and also permitted citizens to drill their own wells. However, because the city was constructed on a layer of peat which was separated from the deep sand layer by only a very thin layer of clay, public and private wells often yielded a mixture of groundwater and polluted infiltration water (Dijkstra 1974). To meet growing demand and expand the supply of good quality drinking water, the city council tried drilling deeper wells, often to find that groundwater was beyond reach, of poor quality, or simply of an insufficient amount (Vogelzang 1956). In 1874, the Water Project was finally carried out, accompanied by a centralized piped water supply plan by Scholten. This plan, in fact, laid the foundation for the city's drinking water company (Van den Noort and Blauw 2000).

The situation of Amsterdam was slightly different. At the beginning of the sixteenth century, with nearly sixty-five thousand inhabitants, the city of Amsterdam was forced to economize on freshwater. A hundred years earlier, the water in the canals had a sufficient self-cleaning capacity, so that inhabitants had only to throw a bucket into the canal for clean water for drinking, washing, and cooking (Groen 1978). But water quality deteriorated: increasing salination of the IJ and Amstel rivers matched by increasing pollution (Leeflang 1943) as the urban population grew and required more water. To clean the water in urban water bodies and canals, the city introduced sluices and mills to the urban water system. The logic was: If polluted canal water could be flushed out of the city, cleaner water could be let in. Around 1675, the city of Amsterdam constructed the stadsvuilwatermolens (wastewater mills) - three horse-drawn mills, each drawn by nine horses - to move dirty water out of the city into the IJ when water levels outside the city rose higher than the city's water level. (Figure 5) The mills proved ineffective and were soon replaced by windmills (Groen 1978; Jurgens and Van der Kaay 2008). 


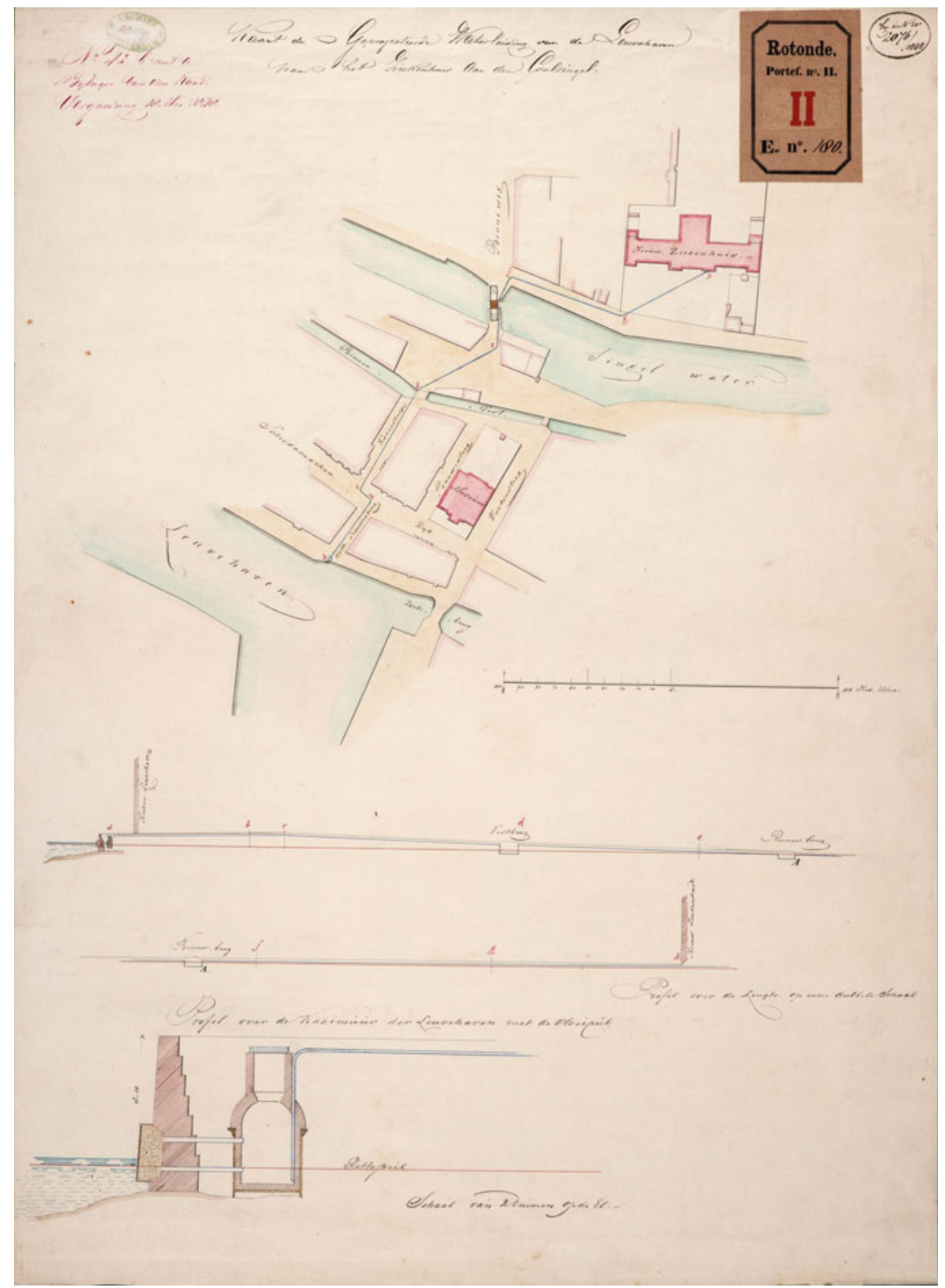

Fig. 3 Detail of plans and profile drawings of a vloeiput at the quay walls of the Leuvehaven and water pipe connecting it to a hospital in the city center of Rotterdam (1848). Source Stadsarchief Rotterdam; released under a Creative Commons Attribution-NonCommercial-NoDerivatives 4.0 International License 


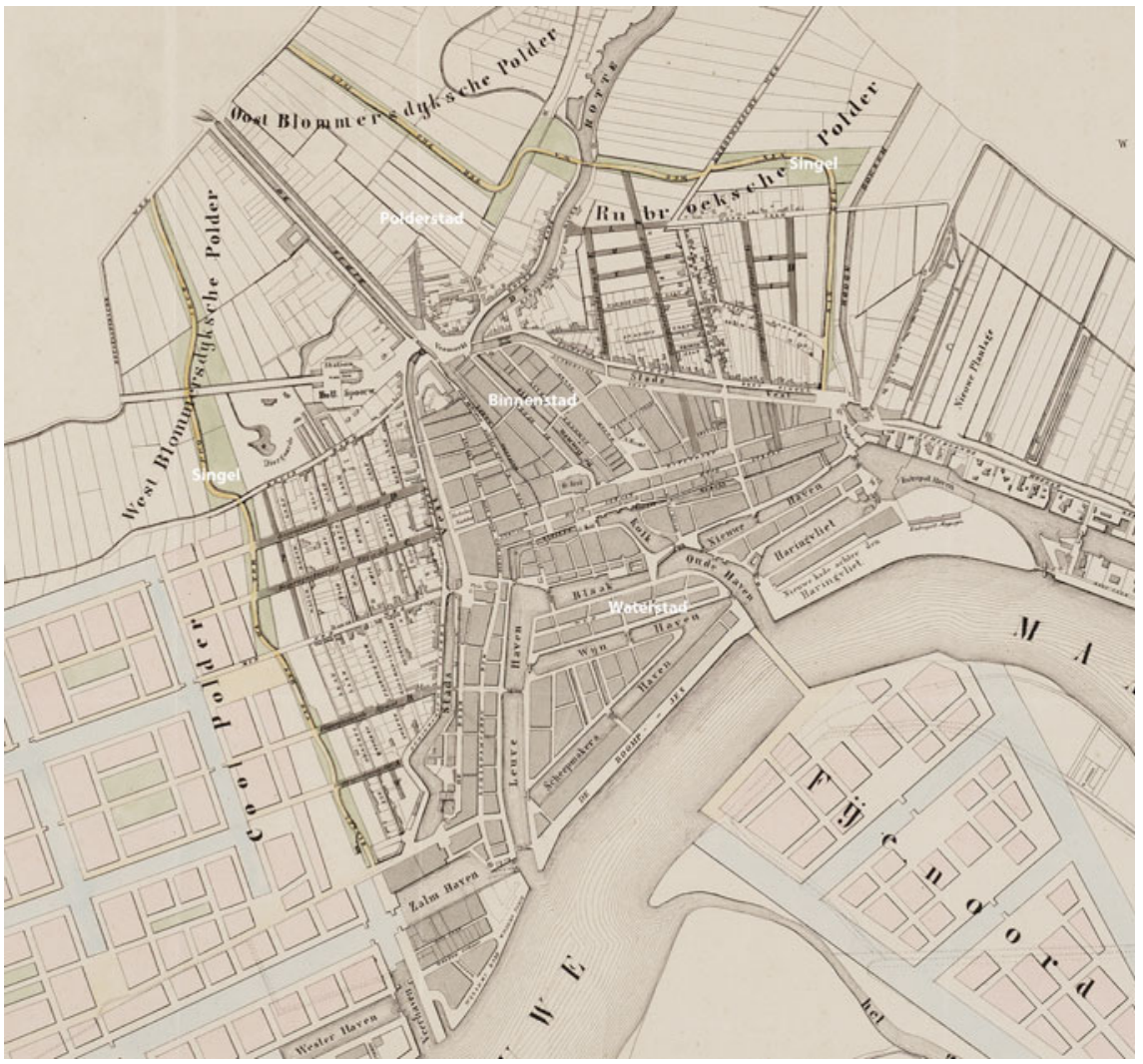

Fig. 4 Detail of the 1858 expansion plan of the city of Rotterdam into the polders, with the new singels to improve the water quality, as part of the water project by city architect Rose. Source Hoogheemraadschap van Schieland en de Krimpenerwaard; released under a Creative Commons Attribution-NonCommercial-NoDerivatives 4.0 International License

The lack of clean water was not only a problem for households but also for industries located within the city walls that required it in large quantities. Amsterdam beer breweries decided as early as 1480 that water obtained from the canals was no longer fit for beer production. They started bringing in water from the Haarlemmermeer, a lake close to the city, in shallow sailing vessels. When the water quality of this lake also deteriorated, they turned to the Vecht River and the Kockengenpolder, a polder forty kilometers from the city (Leeflang 1974). The construction in 1639 of the Weespertrekvaart, a canal with towpaths near the town of Weesp between Amsterdam and the Vecht where drinking water was collected, was of great importance to the urban water supply, improving and simplifying the route (Zondergeld-Hamer 2010). 


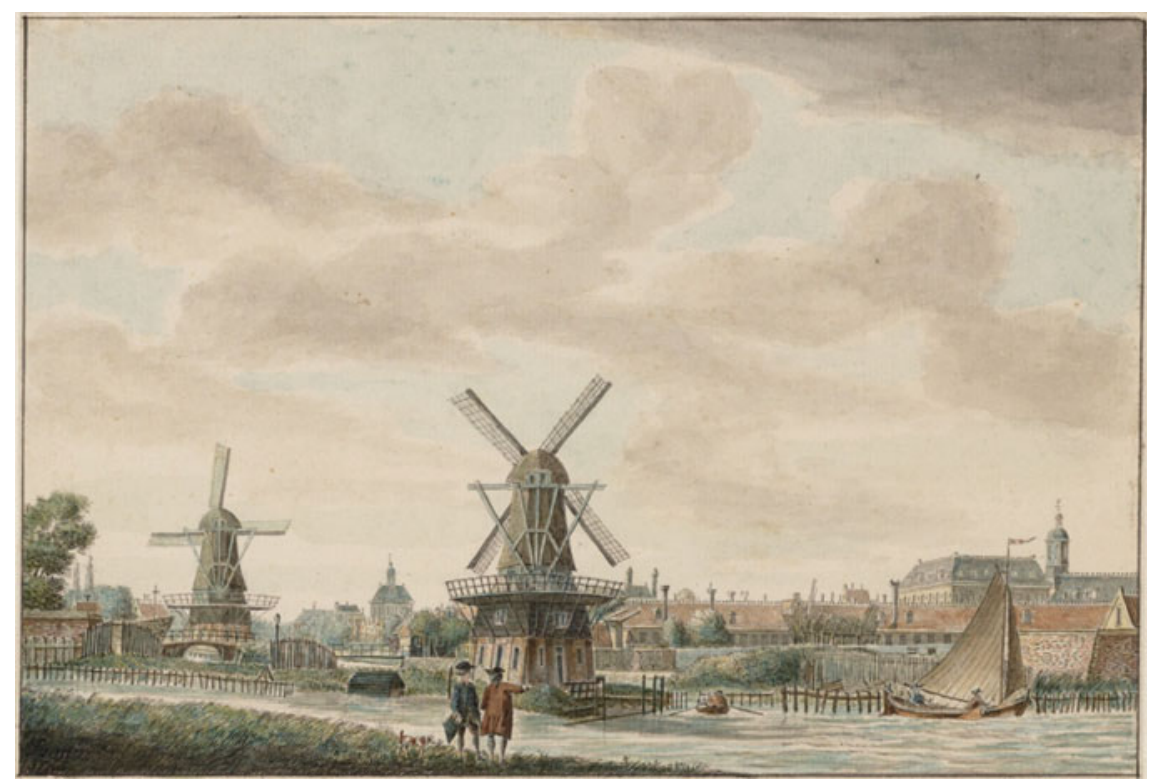

Fig. 5 Drawing of the inner and outer stadsvuilwatermolens (waste water mills) in Amsterdam ca. 1765 by Jan Spaan. Source Stadsarchief Amsterdam; released under a Creative Commons Attribution-NonCommercial-NoDerivatives 4.0 International License

By 1658, a group of Amsterdam brewers collectively invested in a shallow horsedrawn vessel that could break through ice in the waterways to secure water even in harsh winters. If necessary, as many as thirty-six horses could pull the vessel through the thick ice, assisted by men with ice picks. The brewers' water barges supplied the brewers and sold water to the public. Due to its importance to the urban water supply, the icebreaker became the property of the city council in 1786, and a distinction was made between barges selling water to the public and barges supplying the brewers. This protected the public from soaring water prices during droughts and harsh winters. The water vendors organized themselves in the Verschwatersocieteit, or freshwater society (Leeflang 1974). Freshwater from the water barges was transported from boats to smaller vessels that could navigate the smaller canals or to floating platform, where the water was pumped up from beneath the vessel and sold to the public.

Along with riverine water, water stored in the western coastal dune massif was sought after by the beer brewing industry, bleachers, and the urban population (Jelles 1968; Oneindig Noord-Holland 2017). Over the course of centuries, rainwater was stored in the dunes, sometimes to a depth of one hundred meters, pressing down salt 


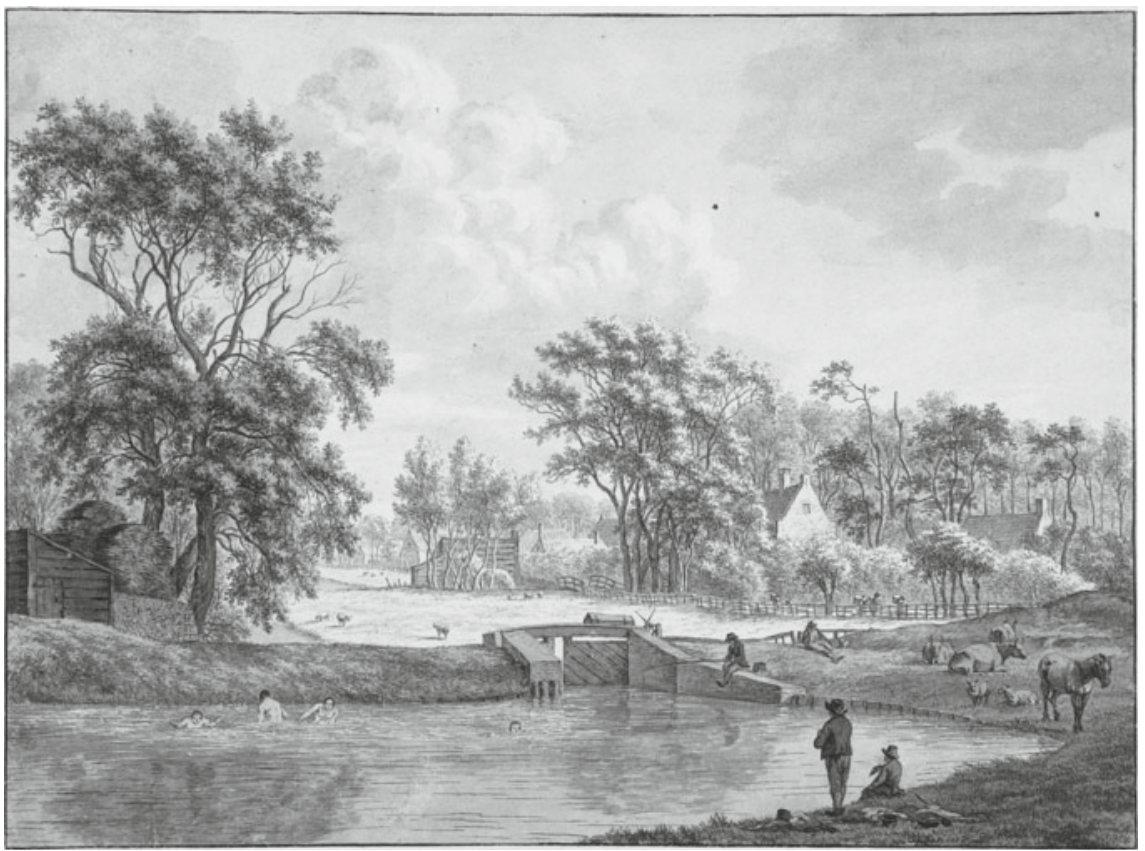

Fig. 6 Drawing of the Brouwerskolk with sluice (1798) by Franciscus Andreas Milatz. Source Noord-Hollands Archief; released under a Creative Commons Attribution-NonCommercialNoDerivatives 4.0 International License

water deposed there. The groundwater level in the dunes, at above sea level, appeared on the surface in valleys and brooks that flowed in a west to east direction. This fresh and clean water was extracted from the sixteenth century until the eighteenth century on a small scale in shallow wells, then transported to cities, and sold to the public (Leeflang 1974). Textile bleachers, dyers, and paper factories had also settled early in this area in the old dunes behind the young dunes to make use of the clean and readily available water (Jelles 1968). Fresh dune water appeared at the surface of the Brouwerskolk, a manmade pool located at the end of the Brouwersvaart canal in the older dunes west of the city of Haarlem. (Figure 6) Water vendors obtained water here and sailed with it back to the city's brewers. The Brouwersvaart, earlier known as the Santvaert, was initially dug to transport sand from the dunes to the cities of Haarlem and Leiden for construction but became both an important transportation route for freshwater and a source of freshwater (Hoekstra 1947; Regtdoorzee Greup-Roldanus 1936). In the nineteenth century, rich bankers from Amsterdam bought land, which included the Brouwerskolk, to build an estate. In 1928, the Brouwerskolk was sold to the city, which converted it into a public park, in that way, protecting it from building development. 


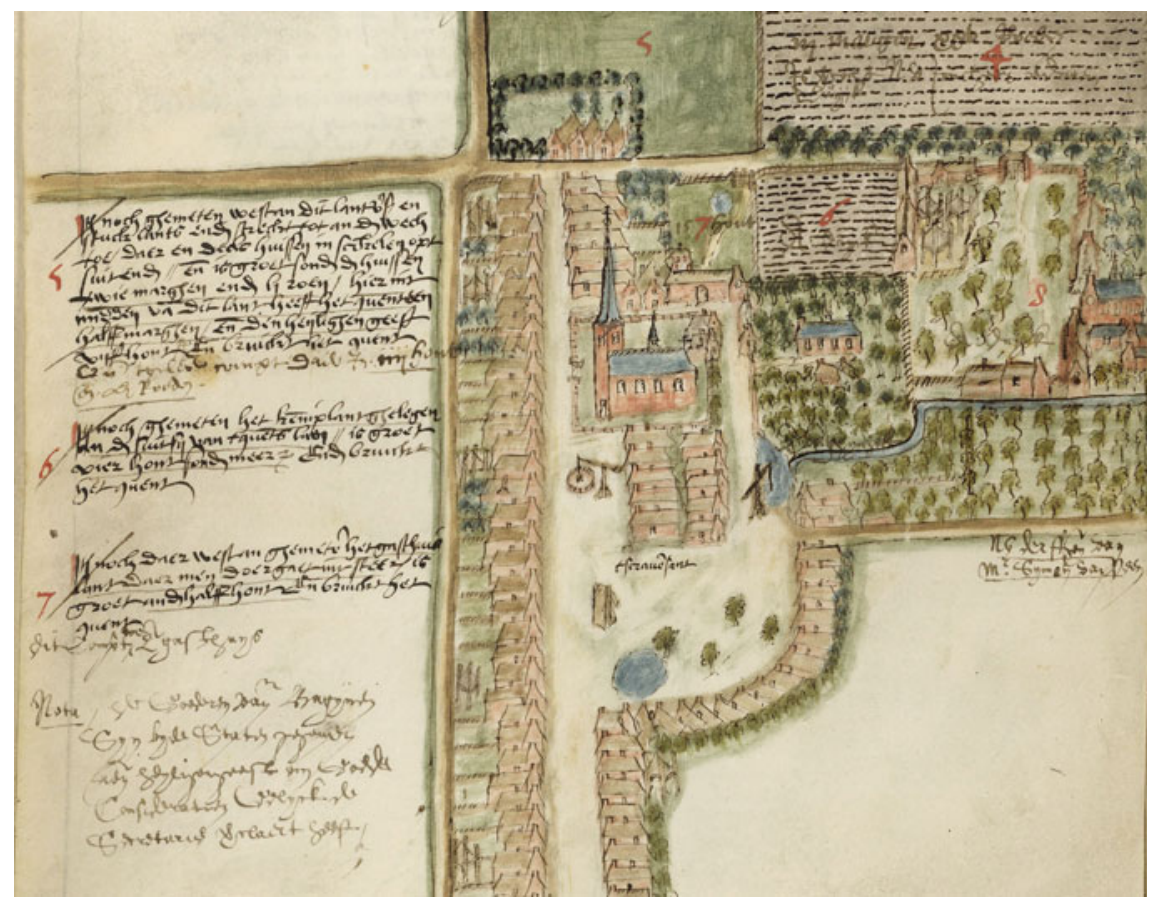

Fig. 7 Detail of map of the town of 's-Gravenzande by Coenraet Oelenzn (1566) with clearly visible public stadswaterputten (wells operated and constructed by the city counsels for its inhabitants) with sweeps. One sweep was located near the harbor, and drinking pools providing both ground and surface water to its inhabitants. Source Nationaal Archief; released under a Creative Commons Attribution-NonCommercial-NoDerivatives 4.0 International License

Along with surface water, the water well was a common typology in water management in the Netherlands. In villages and cities, public wells, often located on squares, were small but important landmarks. (Figure 7) Two types of wells were in use in cities and in rural areas: the rain well for storing and obtaining rainwater and the welput for groundwater. (Rapport aan den Koning 1868) (Fig. 5) A welput reached below groundwater level and was built in a circular shape, from clay bricks which filtered impurities from groundwater seeping into the well. Such structures were usually located on a farm or dwelling but could also be found inside buildings, conveniently located in a stable, for example (Maris 2010). Public versions of these were centrally and strategically located near churches and markets. (Figure 6) Sometimes, the water obtained from them was free of charge, but sometimes a water vendor would charge customers a fee for it. (Vogelzang 1956).

By the eighteenth century, densely populated villages and cities needed more and more public wells to meet the demand for drinking water (Groen 1974). These wells were usually drilled and managed by the local government. By 1871, six 
thousand wells were in use by a population of sixty thousand in the city of Utrecht. Sixty of those wells were reserved for public use (De Bruin et al. 2000); a civil servant in the city of Utrecht, the boormeester, was in charge of drilling and maintaining them ('T Hart 2005).

In the Netherlands, rainwater and surface water were stored in cisterns both large and small (Vogelzang 1956; Zondergeld-Hamer 2010). Larger cisterns were sometimes filled with water brought from the Vecht River (Zondergeld-Hamer 2010). In the province of Zeeland, in parts of West Friesland, Groningen, and Overrijssel, and in cities like Amsterdam, rainwater was traditionally the first or second most important source of water, as surface water was too saline or polluted and groundwater was brackish (Vogelzang 1956; Groen 1978). Rainwater pools or ponds, each with a clay base and walls, can be found in the northern province of Friesland (Leeflang 1974; Baas et al. 2005).

A common type of small rainwater harvesting cisterns was directly connected to a farm, dwelling, or building. This rectangular, lidded, low well, built from bricks, collected rainwater from roofs and sent it through pipes, often made of lead and sometimes a sand filter, into a small underground reservoir. (Figure 8) The water also hosted tench - edible fish - to keep it clean. In the eighteenth century, people became aware of the risk of lead poisoning when using rainwater from large cisterns (Groen 1974). When this was addressed, rainwater was one of the safest water sources available, as it did not spread water-borne diseases (Rapport aan den Koning 1868). In rural and sparsely populated areas, small cisterns were in use into the 1950s. A regular one-family cistern had a volume of about three to five hundred buckets.

To secure the public urban water supply, larger cisterns were located below squares, larger dwellings, public buildings, churches, or courtyards (Fig. 9). Cisterns were also constructed beneath commercial and industrial sites like harbors or tanneries (Gawronsky and Veerkamp 2007). In 1505, the city council of Amsterdam built nine such cisterns to harvest rainwater, as the quality of freshwater from the canals had deteriorated increasingly due to domestic and industrial pollution (Groen 1978). The size and volume of cisterns vary considerably (Gawronsky and Veerkamp 2007). A cistern with a volume of twenty-eight thousand liters was discovered in the foundation of a hothouse-dating back to 1715-at the Amsterdam Botanical Gardens. Research by the city's archeologists suggests this cistern was part of a larger system of interconnected underground water reservoirs both in and outside the grounds of the garden. Rainwater stored in this system was probably used not only for watering the plants but also as a public water reserve in case of drought or fire (Gawronsky and Veerkamp 2007). Construction of a cistern of considerable size was a costly affair and was therefore only affordable for wealthy citizens or businesses (Vogelzang 1956).

The beer brewers of Amsterdam also took an interest in harvesting rainwater. In 1784, Amsterdam brewer Isaac Decker proposed a plan to the city council to build fifty-two freshwater tanks, evenly distributed through the urban territory within the city walls, to secure the water supply for both brewers and inhabitants. Between 1790 


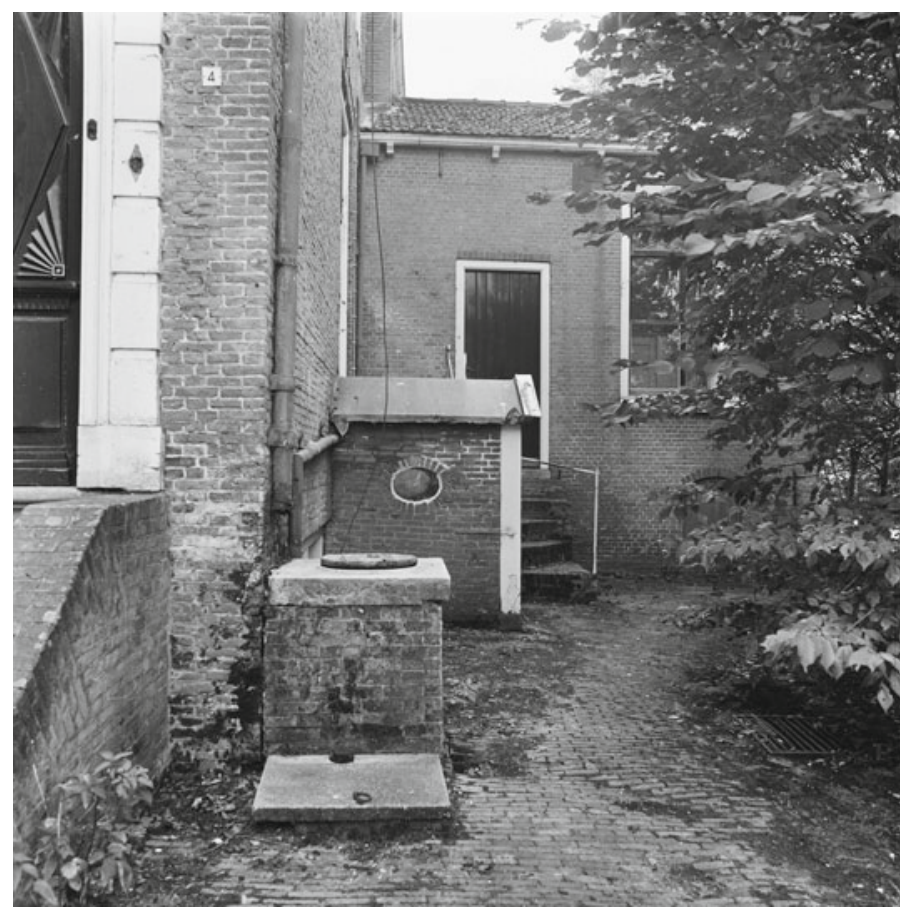

Fig. 8 Two regenputten (rainwater wells) connected to a rainwater pipe. Source Rijksdienst voor het Cultureel Erfgoed; released under a Creative Commons Attribution-NonCommercial-NoDerivatives 4.0 International License

and 1824, thirty-three of the fifty-two were built; twelve of these were exclusively reserved for the breweries (Groen 1978). (Figure 10) However, these rainwater catchment systems (regenputten) actually provided relatively little water. Water imports and surface water therefore remained important sources of urban water.

Outside cities, cisterns were constructed at estates, castles, and fortifications to secure the water supply in times of siege, drought, or natural disaster. Most forts on the Defense Line of Amsterdam and the New Holland Waterline caught rainwater on their sloping, earthen roofs. The water then infiltrated through the sand or earth layers for purification and dripped through small pipes into the cistern (Van Ginkel 2004). This means of diverting and purifying water was much safer and more sustainable than the use of lead pipes.

The water utilities and infrastructure from the Middle Ages to 1853 examined in case studies turn out to be very rich and diverse. The practice of building largescale rainwater harvesting stands out in particular, not only because of the relative obscurity of these systems but also because the practice was so widespread. In fact, both public and private parties initiated, lobbied, and invested heavily in the expen- 


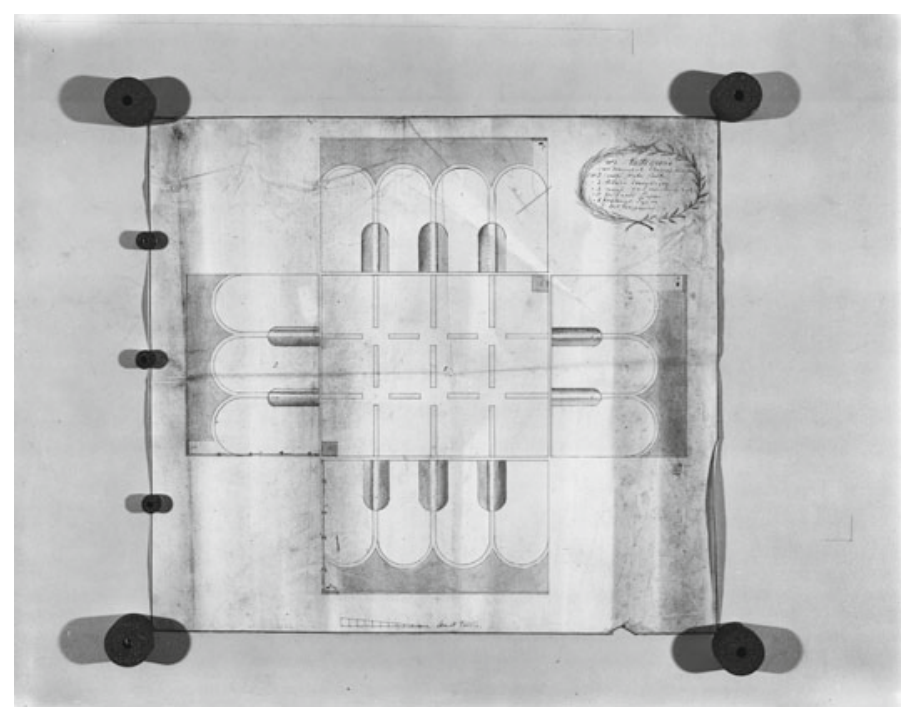

Fig. 9 Drawing of a waterkelder or water cistern for an orphanage in Amsterdam. Source Rijksdienst voor het Cultureel Erfgoed; released under a Creative Commons Attribution-NonCommercialNoDerivatives 4.0 International License

sive construction of cisterns. And while the literature does not mention storm water buffering, the actual or potential storm water buffering capacity of these rainwater harvesting cisterns may have been substantial. Another striking characteristic of the historical water supply systems is that they were sourced from multiple locations and were fit for different purposes. Rainwater, for example, was used only to produce costly drinking water, while surface water and groundwater were used for agricultural or industrial activities. The water supply system was multilayered, featured both small and larger infrastructure and utilities, and was funded and operated by public as well as private parties. This created an awareness and sense of shared responsibility, exemplified in the participation of citizens and private parties in decision making, and the number of private initiatives and investments to secure urban water supplies. From a spatial point of view, the examples of the parksingels of Rotterdam, the Weespertrekvaart of Amsterdam, and the Brouwerskolk in nearby Haarlem were all part of a drinking water supply scheme, are today valued for their contribution to spatial quality but not recognized as integrated components of the water supply systems as such. 


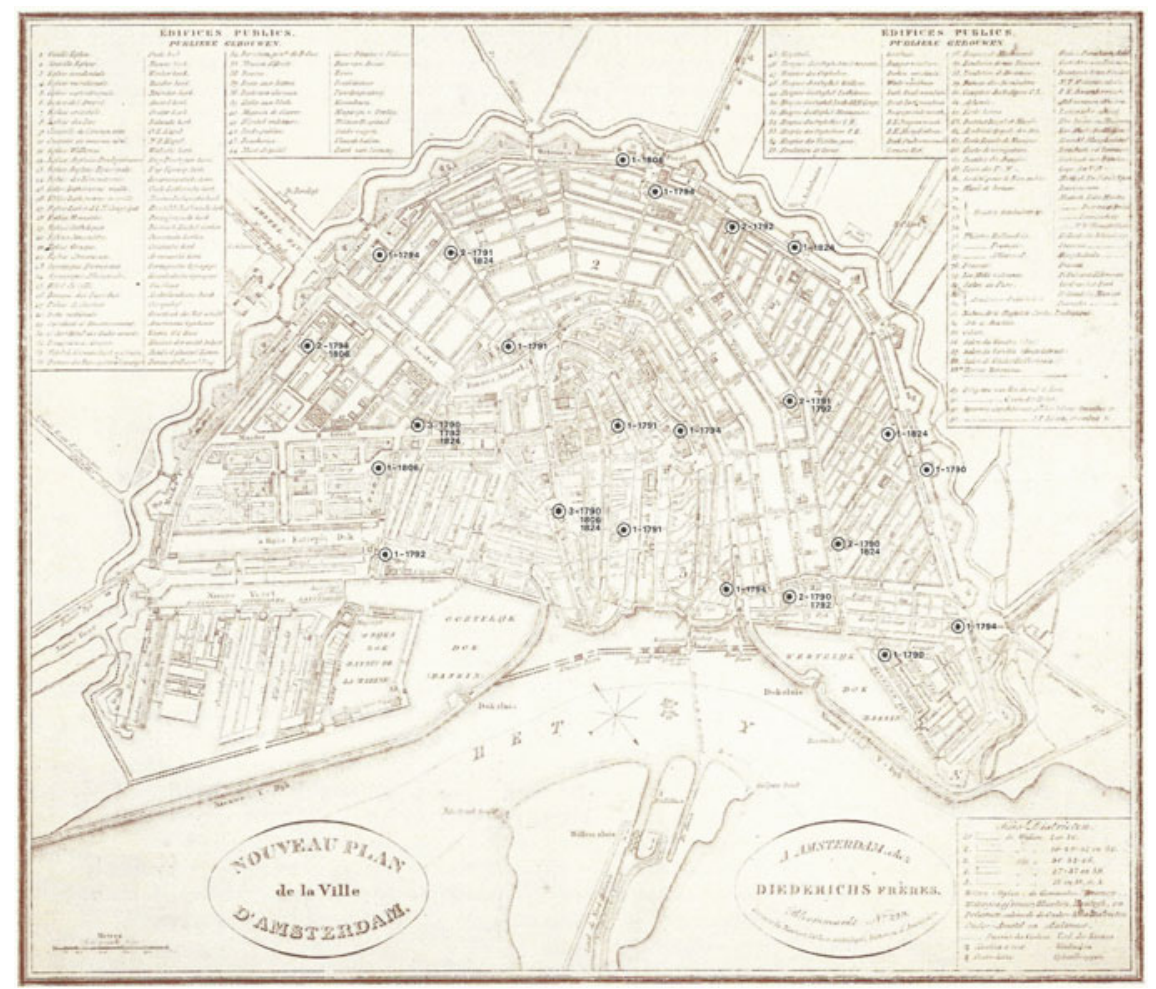

Fig. 10 Map with cisterns in the city of Amsterdam after the plan of beer brewer Isaac Deckers built between 1790 and 1824. Source Groen 1978; released under a Creative Commons AttributionNonCommercial-NoDerivatives 4.0 International License

\section{Piped Systems as Drivers for Nature and Landscape Conservation (1853-Present)}

Dutch cities were relatively late in implementing centralized piped drinking water facilities compared to other European cities (Leeflang 1974). The cities of London and Paris had introduced piped riverine surface water supply systems in the sixteenth and early seventeenth centuries. Finally, on December 12, 1853, citizens collected the first buckets filled with water from the coastal dunes at the Willemspoort fountain in Amsterdam, paying one cent per bucket (Groen 1978). Amsterdam was the first Dutch city with a centralized, piped drinking water supply. However, other cities soon followed.

The Dutch coastal dunes, stretching along the North Sea at its western border, have always been exploited on a smaller scale for their high-quality freshwater. The dunes have also been exploited for sand, wood, and agriculture. There the nobility 


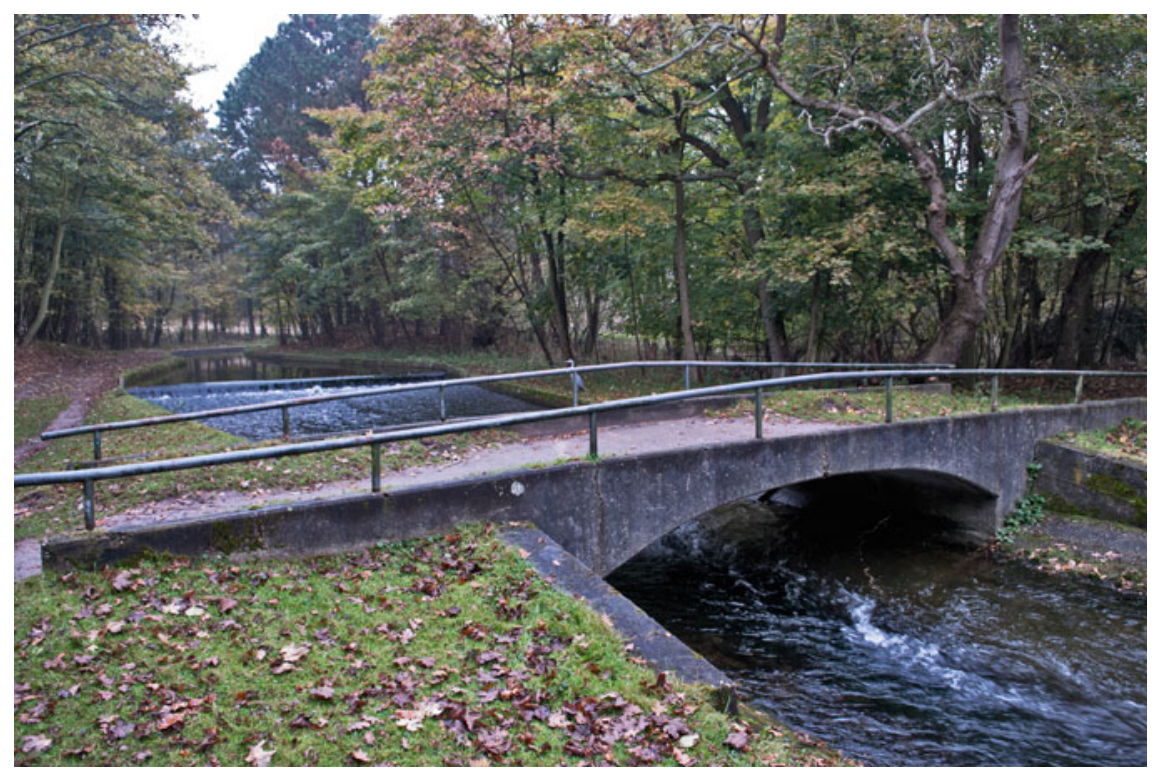

Fig. 11 Canal in the dune water catchment area today. Photograph: Joop Hilster. Source Stichting Waternet; released under a Creative Commons Attribution-NonCommercial-NoDerivatives 4.0 International License

and rich citizens built their estates, with attendant hunting grounds and gardens. Urban water demand led to a private initiative to extract water on an industrial scale from the dunes for the city of Amsterdam. In 1851, the Oranjekom, a water body six meters deep, was dug parallel to the coast in the former wet dune valleys and connected to two canals for phreatic shallow water extraction (Baeyens and Duyve 1992) — that is, to get at water below the water table. This water was first transported by a pipe to a fountain at the Willemspoort in Amsterdam. Soon, more public water taps for distributing piped drinking water, or standpipes, were installed. By 1854, the canals measured three thousand five hundred fifty meters; by 1863 , they were at seven thousand, six hundred twenty meters (Baeyens and Duyve 1992). By 1866, Amsterdam had fifty-six standpipes in use (Groen 1978). Tapping the dune water was so successful that the drinking water company, Duinwater-Maatschappij, struggled to meet demand from Amsterdam. In 1870, a law was passed forcing landowners to sell their dune properties to the Duinwater-Maatschappij so that it could dig more canals to safeguard the urban water supply (Groen 1974). These canals, parallel to the coastline, are distinctive cultural elements that contrast with the coastal dune landscape. (Figs. 11 and 12).

To meet growing demand and to recharge the aquifer and push back the salt water, the Duinwater-Maatschappij decided to inject surface water from the Rhine River into the dunes (Figure 9). They started the process in 1957. The effort turned the 


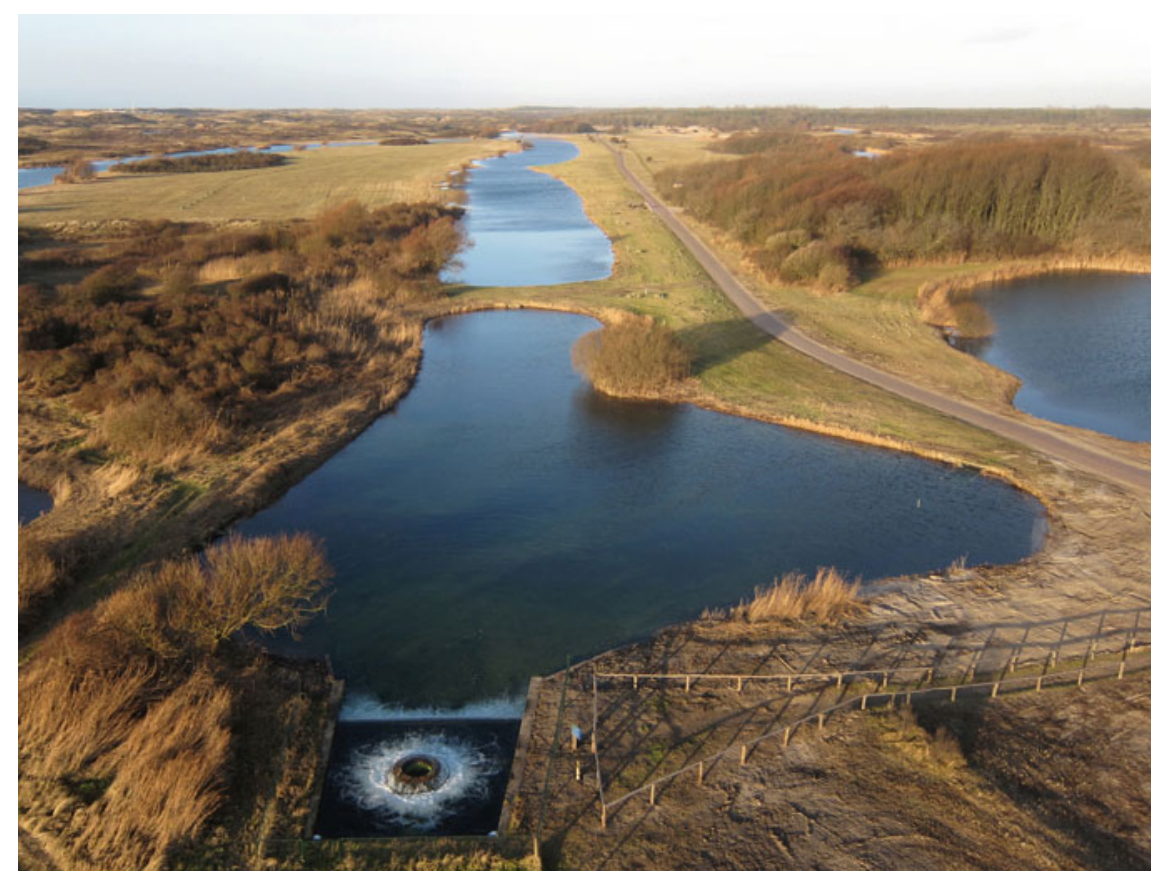

Fig. 12 Infiltration point of surface water from the lake IJsselmeer into the infiltration channels in coastal dunes area of Castricum. Photograph: T. Kisjes

groundwater extraction site into a water purifying plant for riverine surface water; and typical channels were reversed from structures for extraction to infiltration. As unfiltered riverine water threatened the local ecology and the ecosystem of the dunes, riverine water today is first purified before it is put into the dunes (Baeyens and Duyve 1992). Its vital role in the water supply of the city of Amsterdam and the water conservation area's status has protected the area against urban and recreational development.

A unique type of drinking water production is peat lake water extraction in the Bethunepolder. In 1850, the Belgian Marquis Bethune tried to transform a peat lake into a polder by milling water out of it. Unfortunately, seep water continued to appear at the surface of the lakebed, seeping in from a nearby peat lake as well as from the Gooise moraine (Kosman 1988). Because Bethune could not get it fully dry, the lakebed was unfit for agricultural purposes. Plans were then developed to turn the peat lake into a waste dumping area. Luckily, in 1930, the city of Amsterdam decided to exploit the polder for drinking water. Today, one-third of Amsterdam's drinking water comes from the Bethunepolder (Kosman 1988). Seep water from the polder runs through the Waterleidingkanaal (that is, the drinking water canal) 


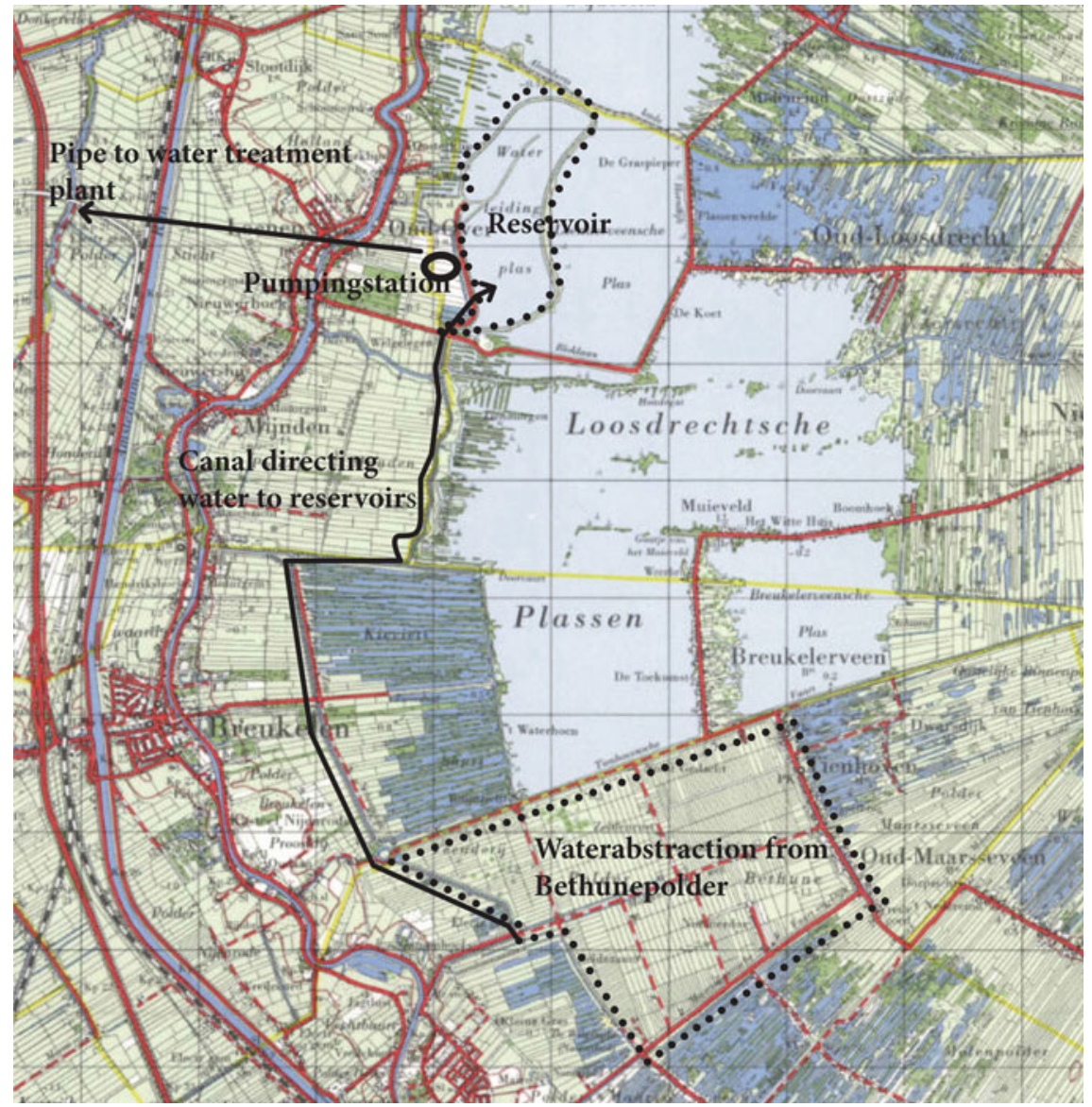

Fig. 13 Map of the peat lake water by ca. 1960. Source Nationaal Archief; released under a Creative Commons Attribution-NonCommercial-NoDerivatives 4.0 International License

to Loenderveense Lake, in a nature conservation area. (Figs. 13 and 14) There, the water is purified before being pumped at the water plant in Weesperkarspel, a district of Amsterdam. The Loosdrechtse peat lake, today an important recreational area, has also been preserved to protect the water supply from the Bethunepolder. The water reservoirs, the Waterleidingkanaal, and treatment plants form a spatial ensemble of both landscape architectural and civil engineering.

Finally, it is important to note that river water has been important to the water supply since the late nineteenth century. Populated areas are often located in river deltas, where surface water was and still is often available, commonly, in large amounts and is easily used. But surface water varies substantially in quality and often requires extensive treatment. In 1870, the Department of Public Works built a surface water 


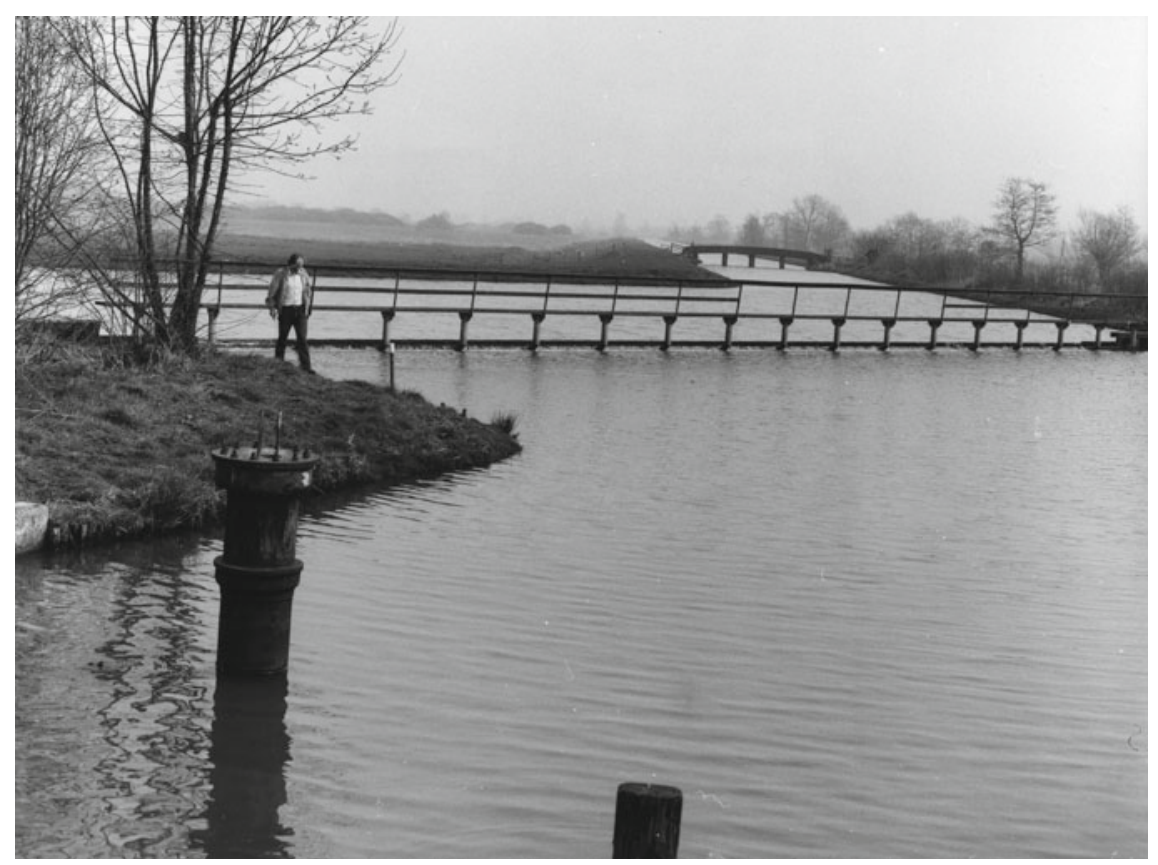

Fig. 14 Drinking water canal (Waterleidingkanaal) transporting seep water from Bethunepolder to the Loenderveenseplas for natural purification (ca. 1988). Source Het Utrechts Archief; released under a Creative Commons Attribution-NonCommercial-NoDerivatives 4.0 International License

treatment plant equipped with a monumental water tower, filter building, and deposit basins east of the city of Rotterdam. The plant extracted water from the Meuse River (Dijkstra 1974). By 1961, the local drinking water company had built a water reservoir and water treatment plant on Beerenplaat Island in the river De Oude Maas with a capacity of eight million cubic meters to meet the growing demand of the city and the water-intensive petrochemical industry in the harbors. However, water quality and quantity still required improvement, and so, the company moved even further away from the city to secure its freshwater demands.

In the early 1970 s, the company built three water reservoirs to purify and store water from the Biesbosch, extensive freshwater tidal wetlands located further upstream, southeast of the city. From these reservoirs, water goes to five drinking water treatment plants, from which the water is distributed as drinking water and water for industry (Van den Noort and Blauw 2000). Due to its importance to the water supply, the Biesbosch has become a protected nature conservation area and an important recreational area (Figs. 15, 16, 17, and 18).

Modern centralized water supply systems did not only herald the beginning of a new era in urban drinking water supply in the Netherlands. It also resulted in the water and landscape conservation of a large area of the coastal dunes, Biesbosch, 


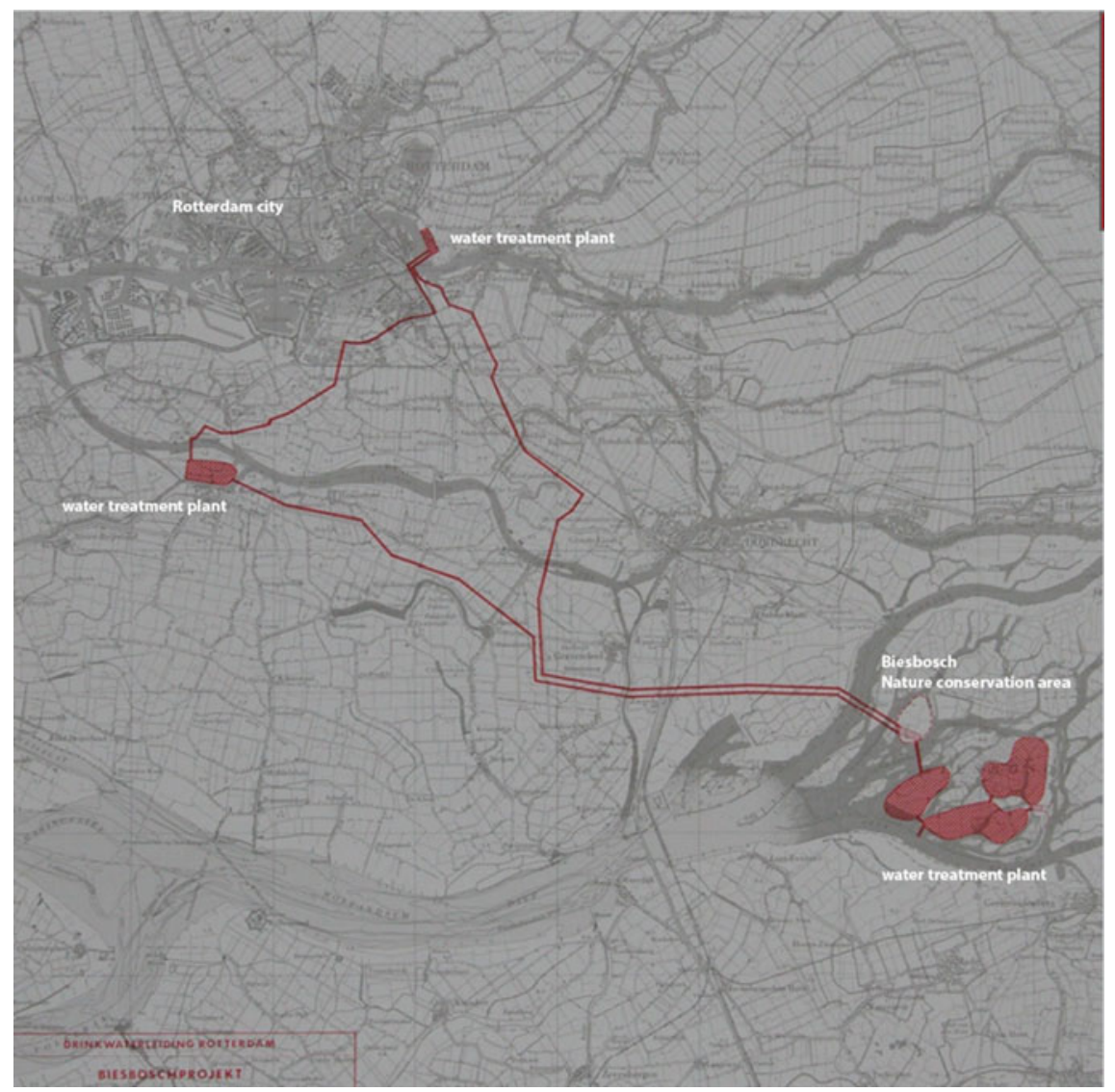

Fig. 15 Map of the Biesbosch project by the water company of Rotterdam in 1967. Source Stadsarchief Rotterdam; released under a Creative Commons Attribution-NonCommercialNoDerivatives 4.0 International License

and peat lake areas, as relatively unspoiled nature reserves and recreation areas. At the same time, drinking water supply utilities like public wells and rainwater cisterns disappeared from the city, out of sight and out of the hands of individual citizens and private parties. Harvesting rainwater, a common practice up until then, was forgotten.

Today, $60 \%$ of drinking water in the Netherlands comes from groundwater (De Moel et al. 2006). Early on, drinking water companies extracted either groundwater or surface water, but the majority of the Dutch drinking water companies now extract groundwater from both shallow and deep confined layers. In the western part of the Netherlands, infiltrated surface water is the main source of drinking water. And along the Rhine, Meuse, Waal, Lek, and IJssel rivers, riverbank groundwater is extracted for this use (De Moel et al. 2006). 


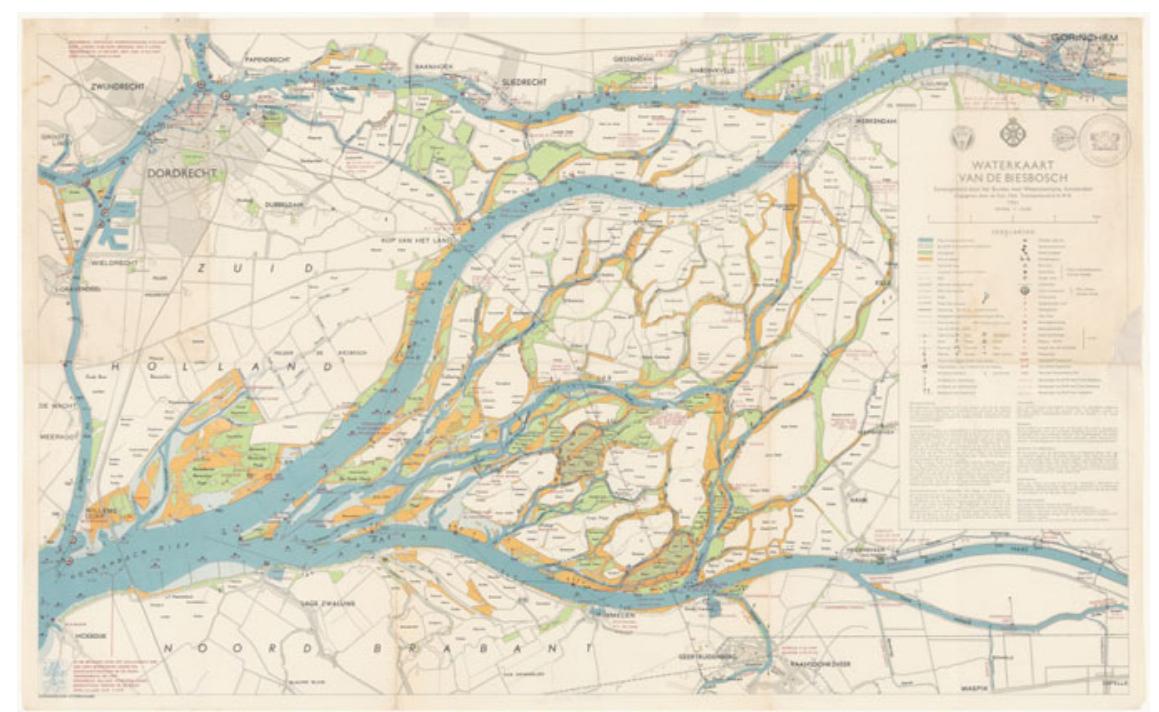

Fig. 16 Map of the freshwater tidal wetlands of the Biesbosch (1961) before the construction of the spaarbekkens (reservoirs). Source Regionaal Archief Dordrecht; released under a Creative Commons Attribution-NonCommercial-NoDerivatives 4.0 International License

\section{Conclusion: Learning from Dutch Water Heritage}

Along with its cultural, spatial, and historical value, Dutch water supply heritage is valuable for its potential to create public awareness on water in and around cities in such ways that this knowledge can be used creatively and effectively to build watersensitive cities and sustainable water utilities systems and networks today and in the future. In sum, the examination of the case studies in this study from the point of view of spatiality raises a few points that are worth noting.

First, the quest for clean drinking water-sometimes deliberately but often unintentionally - was a driver behind the development of urban green and water areas as well as of nature and landscape conservation areas. This fact is not always recognized. Many people in the densely populated urban areas of Rotterdam and Amsterdam enjoy these landscapes and are unaware of their role in the drinking water supply system. Second, the typologies and case studies described in this chapter show that, up to the introduction of piped water and sewer systems, city councils and churches as well as citizens and the private sector cooperated, invested in, and sometimes even exploited rainwater harvesting utilities and water import companies. The challenge is to promote and develop policy and practices that visibly integrate water heritage and historical rainwater harvesting systems more prominently in the public realm. This may help to educate and to engage both citizens and private parties to collaborate in building water-safe and water-secure cities. 
NEDERLAND 1:25000

BIESBOSCH

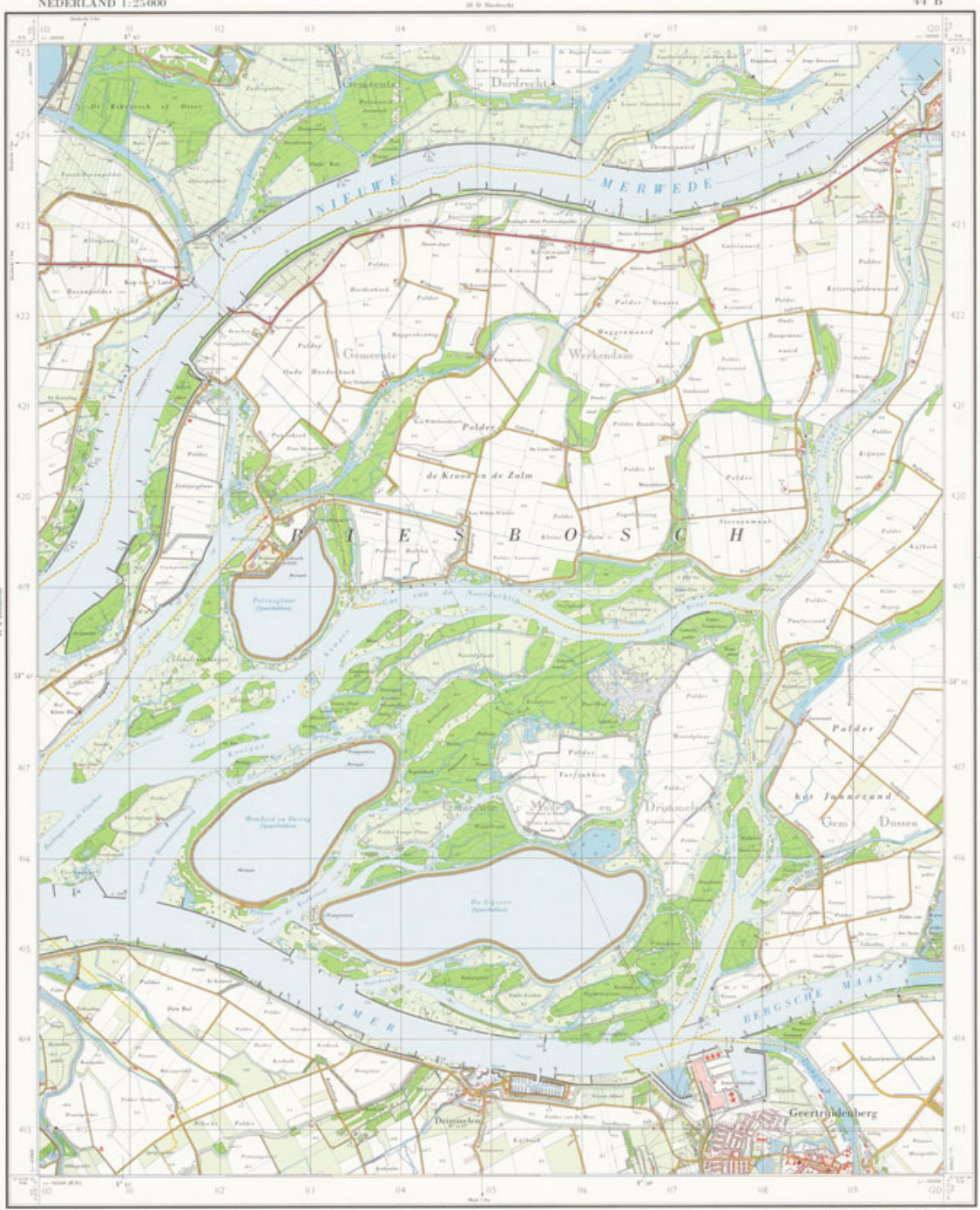

Fig. 17 Map of the freshwater tidal wetlands of the Biesbosch (1988) after the construction of the spaarbekkens (reservoirs). Source Regionaal Archief Dordrecht; released under a Creative Commons Attribution-NonCommercial-NoDerivatives 4.0 International License 


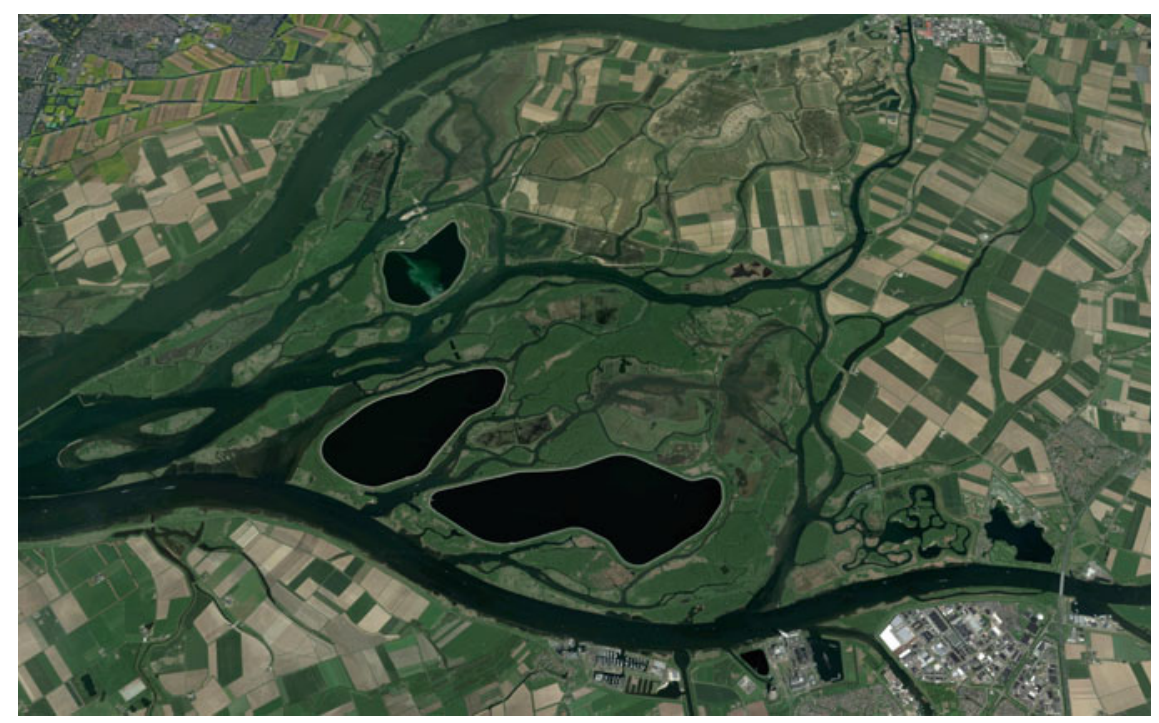

Fig. 18 Three spaarbekkens (water reservoirs) in the Biesbosch national park. Source Google Maps; all rights reserved

Third, Dutch water supply heritage has become invisible or is not recognized, although it embodies valuable solutions and practices such as multisource water supply, private and collective rainwater harvesting, and a combination of off-thegrid, centralized systems that today could have substantial benefits to both water supply and wastewater systems. They could reduce the need for clean drinking water and generate less storm water runoff while engaging citizens and private parties in building water-sensitive and safe cities.

To conclude: Drinking water supply systems and artifacts like public wells, water pumps, infiltration canals, pools, canals, and parksingels transcend the purely utilitarian. As modest but important landmarks they have given meaning to and enhanced urban public space. With the introduction of centralized piped water systems, the urban water supply became an invisible and utilitarian affair. At the same time areas of centralized water extraction and treatment quietly triggered the conservation and development of large nature reserves and recreational areas outside cities. Many enjoy these nature areas but few realize they are navigating the very source of their tap water. 


\section{References}

Baas H, Mobach B, Renes H (2005) Leestekens van het landschap: 188 landschapselemen-ten in kort bestek. Landschapsbeheer Nederland, Utrecht, NL

Baeyens G, Duyve J (1992) Lezen in het Duin. Stadsuitgeverij Amsterdam/Gemeentewaterleidingen Amsterdam, Amsterdam, NL

De Bruin RE et al (red) (2000) 'Een paradijs vol weelde'. Geschiedenis van de stad Utrecht, Matrijs, Utrecht

De Moel P, Verberk J, Van Dijk J (2006) Drinking water: principles and practices. World Scientific Publishing, Singapore

De Vos P (2016) Ergoed Leiden en Omstreken (ELEO). https://www.erfgoedleiden.nl/nieuws/ vondst-van-de-week/692 Retrieved (21 sep 2017)

Dijkstra J (1974) De watermakers: honderd jaar drinkwaterleiding rotterdam. Ge-meente Drinkwaterleiding Rotterdam, Rotterdam

Gawronsky G, Veerkamp J (2007) Water uit de kelder: De verdwenen cisterns van Am-sterdam. Monumenten Archeologie Amsterdam 6, Amsterdam

Groen J (1978) Een cent per emmer: het amsterdamse drinkwater door de eeuwen heen. Gemeentewaterleidingen Amsterdam, Am-sterdam

'T Hart (2005) Leven in Utrecht 1850-1914. Groei naar een moderne stad, Uitgeverij Verloren, Hilversum, blz. 83

Hoekstra P (1947) Proeve ener streekgeschiedenis. Wormerveer

Jelles G (1968) Geschiedenis Van Beheer en Gebruik van het Noord-Hollands Duinreservaat. Instituut voor toegepast biologisch onderzoek in de natuur, Arnhem

Jurgens N, Van der Kaay H (2008). http://www.molendatabase.org/molendb.php?step=details\& nummer=7184. Retrieved (26 Mar 2018)

Kosman H (1988) Drinken uit de plas 1888-1988: honderd jaar Amsterdamse plassenwater-leiding. VEWIN, Rijswijk

Leeflang K (1974) Ons drinkwater in de stroom van de tijd. VEWIN, Rijswijk

Maris A (2010) Van wel- en waterput naar waterleiding op Schiermonnikoog, Cultuurhistorische vereniging 't Heer en Feer', Schiermonnikoog

Oneindig Noord-Holland (2017) Schoon duinwater uit de Brouwerskolk. https://onh.nl/verhaal/ schoon-duinwater-uit-de-brouwerskolk. Retrieved (21 sep 2017)

Rapport aan den Koning (1868) Van de commissie tot onderzoek van drinkwater in verband met den verspreiding van cholera en tot aanwijzing der middelen ter voorziening in zuiver drinkwater. Van Weelden en Mingelen, 's Gravenhage

Regtdoorzee Greup-Roldanus S (1936) Geschiedenis der Haarlemmer bleekerijen. ‘s-Gravenhage Van den Noort J, Blauw M (2000) Water naar zee: Geschiedenis van Waterbedrijf Europoort. NV Waterbedrijf Europoort, Rotterdam

Van Ginkel H (2004) Het rijke verleden van Vestingstad Muiden. Waanders Uitgeverij, Zwolle

Vogelzang I (1956) De drinkwatervoorziening van Nederland vóór de aanleg van drinkwaterleidingen. Rijksuniversiteit te Utrecht, Geografisch Instituut, Utrecht

Wijmer S (1992) Water om te drinken. Rijswijk: Vereniging van Exploitanten van Waterleidingbedrijven in Nederland (VEWIN)

Wijntjes W (1982) The water supply of the medieval town, in: Rotterdam Papers IV: a contribution to medieval archeology 1982

Zondergeld-Hamer A (2010) Van drinken uit de gracht tot kraanwater: De drinkwatervoorziening in Weesp van circa 1850 tot 1907. In: Vrienden van't Gooi \& Tussen Vecht en Eem. 2010 nr. Water Geschiedenis \& Actualiteit. Vereniging van Vrienden van het Gooi Stichting Tussen Vecht en Eem 
Suzanne Loen is a Landscape Researcher, Architect, and Guest Tutor at the Department of Urban Planning and Landscape Architecture at Delft University of Technology. Her publications include Land inSight and Water inSight. Her research includes Dutch water management and the sustainable redesign of industrial kampungs in the peri-urban landscape of Bandung, Indonesia.

Open Access This chapter is licensed under the terms of the Creative Commons AttributionNonCommercial-NoDerivatives 4.0 International License (http://creativecommons.org/licenses/bync-nd/4.0/), which permits any noncommercial use, sharing, distribution and reproduction in any medium or format, as long as you give appropriate credit to the original author(s) and the source, provide a link to the Creative Commons license and indicate if you modified the licensed material. You do not have permission under this license to share adapted material derived from this chapter or parts of it.

The images or other third party material in this chapter are included in the chapter's Creative Commons license, unless indicated otherwise in a credit line to the material. If material is not included in the chapter's Creative Commons license and your intended use is not permitted by statutory regulation or exceeds the permitted use, you will need to obtain permission directly from the copyright holder.

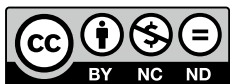

